\title{
STATUS VITAMIN A DAN ZAT BESI ANAK INDONESIA
}

\author{
Fitrah Ernawati ${ }^{1,3}$, Sandjaja ${ }^{1,3}$, Moesijanti Y.E. Soekatri ${ }^{1,3}$ \\ ${ }^{1}$ Pusat Teknologi Terapan Kesehatan dan Epidemiologi Klinik \\ 2Jurusan Gizi, Politeknik Kesehatan Kemenkes Jakarta II \\ 3Persatuan Ahli Gizi Indonesia (PERSAGI) \\ fitrahernawati@yahoo.com
}

\begin{abstract}
ABSTRAK
Zat besi dan vitamin A mempunyai peran penting dalam pertumbuhan anak. Kekurangan kedua zat gizi tersebut mempunyai dampak yang luas terhadap, tumbuh kembang anak. Tulisan ini bertujuan untuk mengetahui status anemia dan status vitamin A anak Indonesia. SEANUTS adalah survai status gizi anak 0,5-12,9 tahun multi-center study dengan rancangan potong lintang yang dilaksanakan pada tahun 2011 di Indonesia yang mencakup 48 kabupaten/kota. Data yang dikumpulkan antara lain biokimia darah, termasuk hemoglobin, ferritin, dan vitamin A serum. Penentuan kadar hemoglobin dengan Cyanmethemoglobin, ferritin dengan ELISA, kadar serum vitamin A menggunakan HPLC. Hasil penelitian menunjukkan prevalensi anemia tertinggi ditemukan pada kelompok umur 0,5-0,9 tahun yang tinggal di perdesaan yaitu 61,9 persen dibandingkan pada kelompok umur 9,0-12,9 tahun yaitu 11,4 persen. Demikian pula dengan prevalensi kurang besi, pada kelompok umur 1,0 - 2,9 tahun sebesar 29,7 persen, sedangkan pada kelompok umur 9,0-12,9 tahun hanya 5,3 persen. Prevalensi kekurangan vitamin $A$ di perkotaan, pada kelompok umur 1,0-2,9 tahun tidak dijumpai masalah kurang vitamin $A$ (0,0 persen), namun di perdesaan dijumpai sebanyak 3,1 persen, sementara itu pada kelompok usia 9,0-12,9 tahun di perkotaan dijumpai sebesar 4,9 persen dan di perdesaan sebesar 4,8 persen. Anemia masih menjadi masalah kesehatan masyarakat dengan kategori berat terutama pada anak di bawah usia 3 tahun. Kekurangan zat besi lebih banyak ditemui pada anak kelompok usia dibawah 3 tahun.
\end{abstract}

Kata kunci: status vitamin A, status besi, anak Indonesia

ABSTRACT

\section{VITAMIN A AND IRON STATUS OF INDONESIAN CHILDREN}

The aim of this study was to identify the iron and vitamin A status in Indonesian children. SEANUTS Indonesia covered children of age 0.5-12.9 years old from 48 sub-districts. The study collected biochemical parameters which included iron, ferritin and serum vitamin A status. Hemoglobin was determined by Cyanmethemoglobin, ferritin by ELISA and serum vitamin A serum by HPLC. The prevalence of anemia was lower $(11.4 \%)$ in the older children $(9.0-12.9$ years) compared to younger children (0.5-0.9 years) were $61.9 \%$ which was found in the rural area. Similarly, the prevalence of iron deficiency was lower (5.3\%) in the older children (9.0-12.9 years) compared to younger children (0.5-0.9 years) were $29.7 \%$ which was found in the rural area. In contrast, the prevalence of retinol deficiency was higher (4.9\%) in the older children (9.0-12.9 years) compared to younger children (0.5-0.9 years) were 0,0 $\%$ which was found in the urban area, and it was higher $(4.8 \%)$ in the older children (9.0-12.9 years) compared to younger children (0.5-0.9 years) were $3.1 \%$ which was found in the rural area. Anemia among children under 3 years old remains a severe public health problem. Iron deficiency more prevalent among children under 3 years old.

Keywords: vitamin A status, iron status, Indonesian children

\section{PENDAHULUAN}

A nemia masih menjadi salah satu masalah gizi di Indonesia, terutama pada kelompok rentan seperti pada anak berusia di bawah lima tahun. Riset Kesehatan Dasar 2007 menunjukkan bahwa 27,7 persen anak usia 1-4 tahun dan 9,4 persen anak usia 5-14 tahun menderita anemia. ${ }^{1}$ Temuan ini tidak jauh berbeda dengan penelitian lain yang dilakukan di DKI Jakarta, anak berusia 2-4 tahun yang menderita anemia sebesar 26,8 persen ${ }^{2}$. Hal ini menunjukkan bahwa masalah anemia masih menjadi masalah kesehatan 
masyarakat di Indonesia. Menurut WHO anemia dinyatakan sebagai masalah kesehatan masyarakat, bila prevalensi lebih dari 5 persen. ${ }^{3}$ Penyebab anemia di Indonesia terbesar adalah kekurangan zat besi. ${ }^{4}$ Dampak anemia kurang besi sangat luas di antaranya gangguan perkembangan psikomotor, gangguan fungsi kognitif dan gangguan pertumbuhan. ${ }^{4}$

Selain anemia, kekurangan vitamin A (KVA) juga masih menjadi masalah kesehatan masyarakat, terutama di negara berkembang. Prevalensi kurang vitamin A (kadar vitamin $A<0,70 \mu \mathrm{mol} / \mathrm{l})$ pada anak balita yakni 11,4 persen. ${ }^{5}$ Hasil ini sejalan dengan temuan di Negara Vietnam, yang menunjukkan 10,7 persen anak usia 12-72 bulan kekurangan vitamin $\mathrm{A}(<0,7 \mu \mathrm{mol} / /)^{6}$, pada penelitian yang sama ditemukan 41,2 persen anak mempunyai kadar vitamin A antara 0,70-1,04 $\mu \mathrm{mol} / / \mathrm{l}$ sebagai indikasi status vitamin A marginal (suboptimal), sehingga anak anak tersebut rentan terhadap terjadinya kekurangan vitamin $A .{ }^{6}$ Kekurangan vitamin A merupakan salah satu penyebab terjadinya gagal tumbuh, penurunan respon imunitas dan yang paling mengkhawatirkan merupakan risko tinggi terjadinya xerophthalmia dan kebutaan. ${ }^{4}$

Oleh karena status besi dan vitamin A mempunyai peran penting dan mempunyai dampak yang luas terhadap tumbuh kembang anak maka penelitian ini bertujuan untuk mengidentifikasi status besi dan vitamin A pada anak usia 0,5-12 tahun.

\section{METODE PENELITIAN}

Penelitian ini merupakan bagian dari penelitian SEANUTS (South East Asian Nutrition Survey). Sampel penelitian adalah anak usia 6 bulan sampai dengan 12 tahun. Kriteria inklusi adalah sehat secara fisik dan klinis yang diperiksa oleh dokter. Orangtua anak mengijinkan anak diikutkan dalam penelitian. Jumlah anak seluruhnya 7211 , tetapi jumlah anak yang diperiksa darah untuk analisis hemoglobin sebanyak 2576 anak dan untuk analisis serum retinol sebanyak 1672 anak. Anak yang diperiksa retinol hanya anak umur 2,0-12,9 tahun, sedangkan untuk pemeriksaan $\mathrm{Hb}$ adalah semua kelompok umur yaitu 0,5-12,9 tahun.

Pengambilan darah pada anak berusia 623 bulan dilakukan melalui jari/tumit (darah tepi). Anak pada kelompok ini hanya diperiksa hemoglobin $(\mathrm{Hb})$. Metode Cyanmethemoglobin dengan alat Hemocue, digunakan menentukan kadar $\mathrm{Hb}$. Pada kelompok anak lebih tua $(2,0$ 12,0 tahun), darah anak diambil dari vena mediana cubiti. Kemudian darah vena dibagi menjadi dua bagian, yaitu darah dengan EDTA dan darah tanpa antikoagulan (plain). Darah dengan EDTA digunakan untuk pengukuran profil darah yaitu hemoglobin, lekosit, eritrosit, $\mathrm{MCH}, \mathrm{MCV}, \mathrm{MCHC}$. Darah tanpa antikoagulan dimasukkan dalam vacutainer untuk dilakukan sentrifus/pemutaran, kemudian hasilnya dipisahkan bagian jernih yaitu serum dari endapan sel-sel darah. Serum dibagi menjadi 2 (dua) vial ukuran $1,5 \mathrm{ml}$, masing masing vial berisi $0,5 \mathrm{ml}$. Vial-vial tersebut ditempatkan dalam rak tabung dan selanjutnya disimpan dalam cool box dengan suhu kurang lebih $-4^{\circ} \mathrm{C}$. Serum dalam cool box tersebut dikirim ke laboratorium $\mathrm{P}$ untuk disimpan dalam freezer suhu $-80^{\circ} \mathrm{C}$ sebelum dilakukan analisa vitamin A, AGP, CRP, Vitamin D, ferritin. Dalam penulisan artikel ini hanya disajikan hasil pemeriksaan $\mathrm{Hb}$, retinol (vitamin $\mathrm{A}$ ) serum dan feritin serum.

Vitamin A dikatakan defisiensi apabila kadar vitamin A serum $<0,7 \mu \mathrm{mol} / \mathrm{l}$. Anemia adalah keadaan seseorang yang mempunyai kadar $\mathrm{Hb}$ di bawah nilai normal sesuai kelompok umur dan jenis kelamin. Untuk anak yang berusia $6-59$ bulan batas kadar $\mathrm{Hb}<110$ $\mathrm{g} / \mathrm{l}$, anak 5-11 tahun batas kadar $\mathrm{Hb}<115 \mathrm{~g} / \mathrm{l}$, dan anak 12-14 tahun batas kadar $\mathrm{Hb}<120 \mathrm{~g} / \mathrm{l}^{3}{ }^{3}$

Kadar feritin dikatakan defisiensi apabila kadar feritin < 12 ug/l untuk anak umur < 5 tahun, dan apabila kadar feritin $<15$ untuk anak umur $>=5$ tahun. ${ }^{3}$ Untuk menggambarkan populasi, analisis data dilakukan pembobotan (weighting).

Kadar $\mathrm{Hb}$ diukur dengan Spectrophotometer pada panjang gelombang $540 \mathrm{~nm}$. Pengukuran di laboratorium terakreditasi. Serum beku dicairkan dalam suhu kamar sebelum dilakukan pencampuran dengan reagensia. Kemudian kadar retinol serum dianalisa dengan menggunakan HPLC.

Kriteria anemia bukan karena kurang besi apabila kadar $\mathrm{Hb}$ tidak normal (anemia) dan kadar feritin normal, sedangkan anemia gizi besi apabila kadar $\mathrm{Hb}$ tidak normal (anemia) dan kadar feritin rendah/kurang. 
Data dianalisis secara deskriptif dan uji bivariat dengan Chi-square.

\section{HASIL}

Tabel 1 menunjukkan bahwa proporsi anak paling besar pada kelompok umur 6,0-8,9 tahun yaitu 33,2 persen, proporsi yang tinggal di perdesaan $(56,4 \%)$ lebih besar dibandingkan yang tinggal di perkotaan $(43,6 \%)$. Sementara itu, proporsi anak laki-laki $(49,4 \%)$ hampir sebanding, dengan anak perempuan $(50,6 \%)$.

Adanya perbedaan jumlah sampel pada karakteristik daerah (2577) dengan jenis kelamin dan distribusi kelompok umur (2576) disebabkan karena pengaruh weighting (pembobotan).

Tabel 1

Karakteristik Sampel menurut Kelompok Umur, Daerah, dan Jenis Kelamin

\begin{tabular}{ccc}
\hline Karakteristik Sampel & $\begin{array}{c}\text { Jumlah sampel } \\
\text { (anak) }\end{array}$ & Persen \\
\hline Umur (tahun) & & \\
- $0,5-0,9$ & 148 & 5,7 \\
- $1,0-2,9$ & 430 & 16,7 \\
- $3,0-5,9$ & 607 & 23,6 \\
- $\quad 6,0-8,9$ & 856 & 33,2 \\
- 9,0-12,9 & 535 & 20,8 \\
- Total & 2576 & 100,0 \\
\hline Daerah & & \\
- Perkotaan & 1124 & 43,6 \\
- Perdesaan & 1453 & 56,4 \\
- Total & 2577 & 100,0 \\
\hline Jenis Kelamin & & \\
- Laki-laki & 1272 & 49,4 \\
- Perempuan & 1304 & 50,6 \\
- Total & 2576 & 100,0 \\
\hline
\end{tabular}

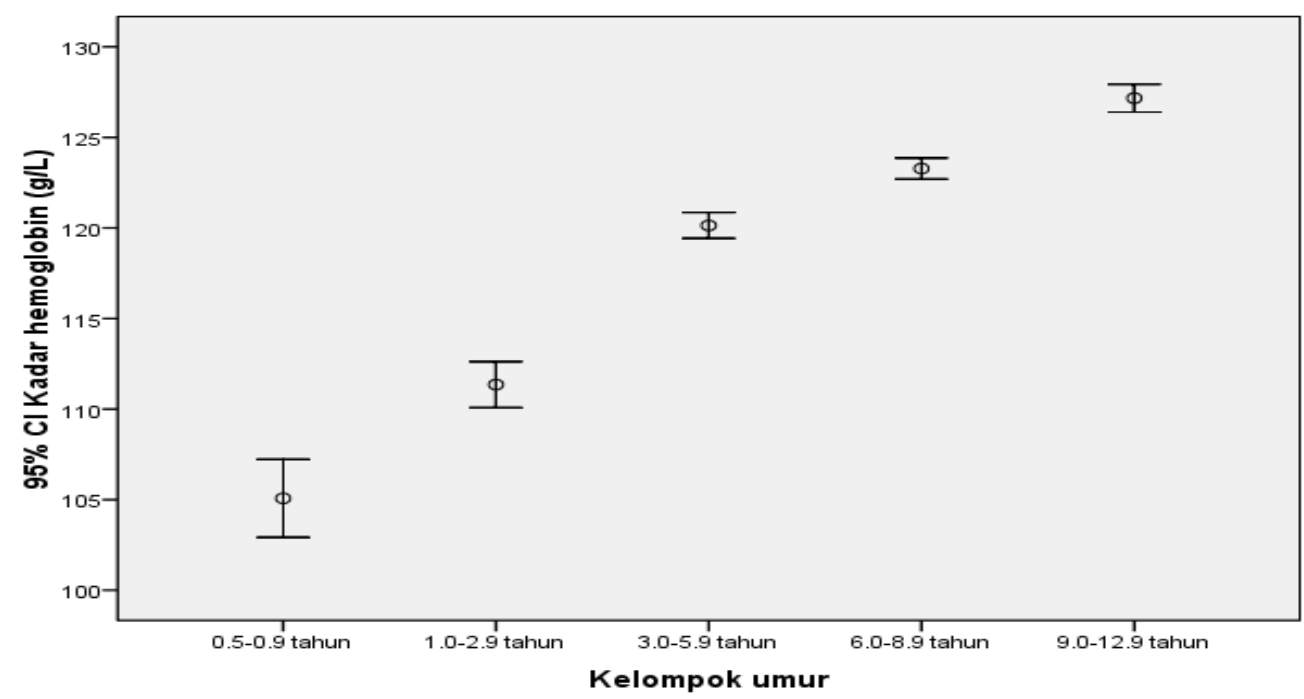

Gambar 1

Rerata Kadar Hb (g/l) Anak menurut Kelompok Umur 
Rerata kadar $\mathrm{Hb}$ anak lebih tinggi pada kelompok anak yang berumur lebih tua. Rerata kadar $\mathrm{Hb}$ kelompok anak berumur 0,5-0,9 tahun yaitu $105 \pm 1,1 \mathrm{~g} / \mathrm{l}$ dan rerata tampak lebih tinggi pada kelompok yang lebih tua. Kelompok anak umur tertua (9,0-12,9 tahun) rerata tertinggi yaitu sebesar $127 \pm 0,4 \mathrm{~g} / \mathrm{l}$. (Gambar 1).
Gambar 2. menunjukkan rerata kadar ferritin anak yang lebih tinggi pada kelompok anak berumur lebih tua. Kadar ferritin kelompok anak berumur 1,0-2,9 th sebesar $29 \pm 1,7 \mathrm{ug} / \mathrm{l}$ dan kelompok paling tua $(9,0-12,9$ th) sebesar $54 \pm 1,4 \mathrm{ug} / \mathrm{l}$

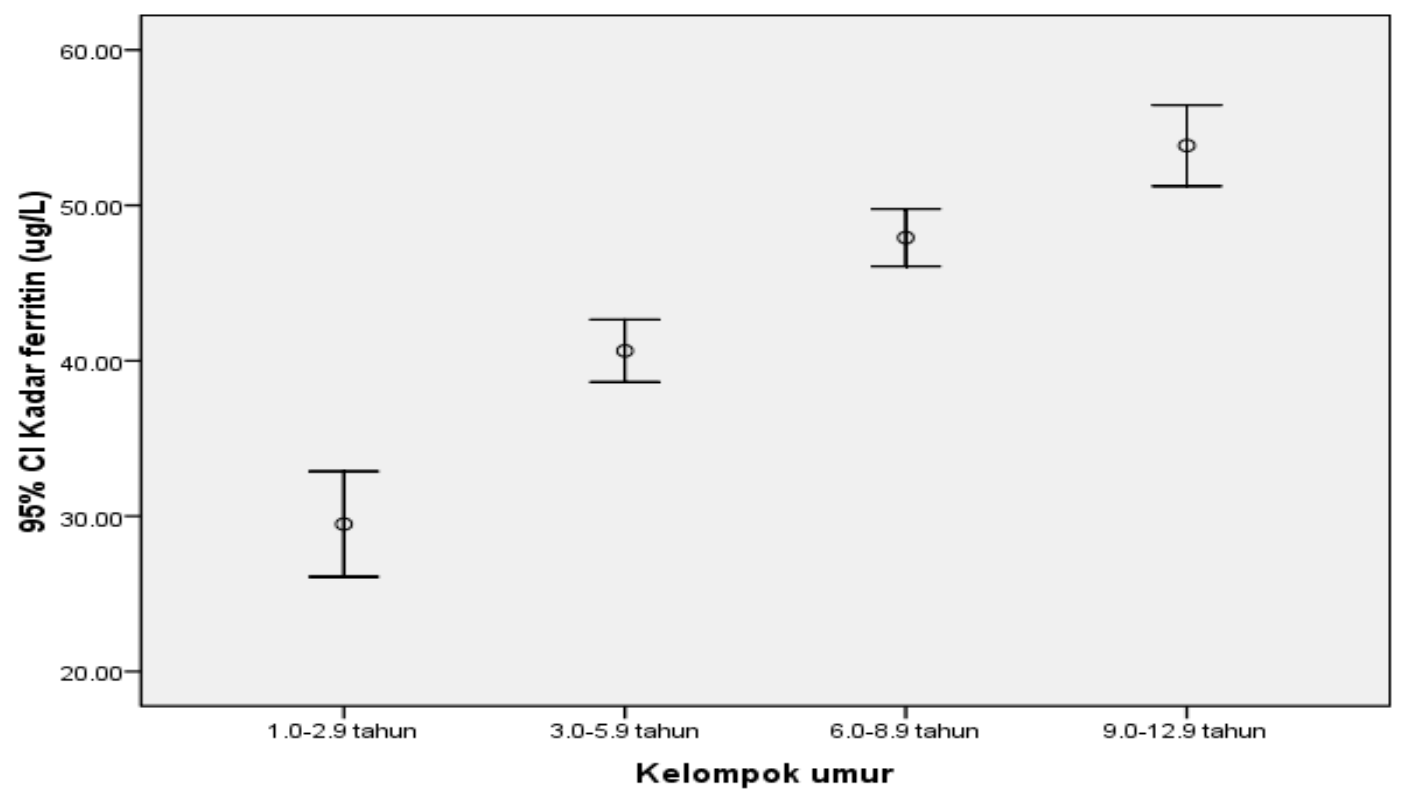

Gambar 2

Rerata Kadar Ferritin (ug/l) Anak menurut Kelompok Umur

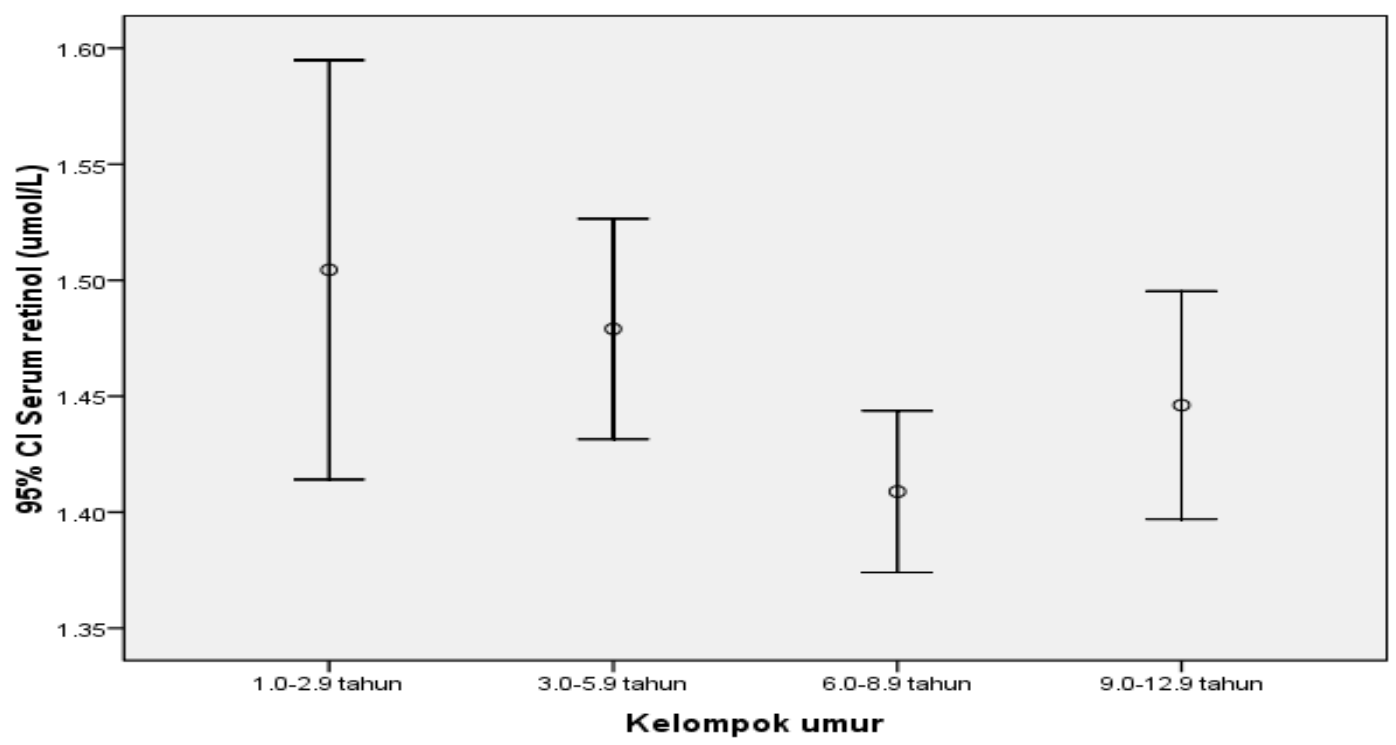

Gambar 3

Rerata Kadar Vitamin A Serum menurut Kelompok Umur 
Gambaran rerata kadar vitamin A anak rendah pada kelompok anak berumur muda dan lebih tinggi pada kelompok anak berumur lebih tua. Rerata kadar vitamin A kelompok anak

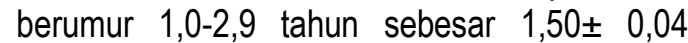
umol/l, kemudian lebih kecil pada kelompok anak berumur 6,0-8,9 tahun yakni 1,42 $\pm 0,02$ umol/l, selanjutnya sedikit lebih tinggi pada umur 9,0-12,9 tahun yakni $1,44 \pm 0,03$ umol// (Gambar 3).

Adapun sebaran prevalensi anemia dan kurang zat besi disajikan pada Tabel 2 . Prevalensi anemia pada anak menunjukkan keadaan yang lebih rendah pada kelompok umur anak yang lebih tua. Prevalensi anemia tinggi pada kelompok usia muda (0,5-0,9 tahun) sebesar 54,7 persen di perkotaan dan 61,9 persen di perdesaan. Sedangkan pada anak usia tua (9,0-12,9 tahun) sebesar 5,0 persen di perkotaan dan 11,4 persen di perdesaan. Pola yang sama ditemukan pada prevalensi kurang zat besi. Prevalensi kurang besi tinggi pada kelompok usia muda (0,5-0,9 tahun) sebesar 17,2 persen di perkotaan dan 29,7 persen di perdesaan dibandingkan pada anak usia tua (9,0-12,9 tahun) sebesar 0,9 persen di perkotaan dan 5,3 persen di perdesaan.

Tabel 3 menunjukkan bahwa prevalensi kurang vitamin $A(K V A)$ dengan kadar vitamin $A$ kurang dari $0,7 \mathrm{umol} / \mathrm{l}$ ditemukan paling tinggi pada kelompok umur 9,0-12,9 tahun yaitu di perkotaan 4,9 persen dan di perdesaan 4,8 persen dibandingkan pada kelompok usia 1,02,9 tahun yaitu 3,1 persen di perdesaan, namun tidak ditemukan di perkotaan. Anak umur 0,50,9 tahun tidak diperiksa vitamin $A$, karena harus diambil darah melalui vena.

Tabel 4 menunjukkan proporsi anak yang mengalami anemia dan anemia kurang besi. Prevalensi anemia tinggi dijumpai pada kelompok usia muda (1,0-2,9 tahun) sebesar 37,3 persen dimana 17,0 persen adalah anemia kurang besi dibandingkan pada anak usia tua (9,0-12,9 tahun) proporsi anemia sebesar 7,9 persen dimana 1,2 persen adalah anemia kurang besi.

Tabel 2

Prevalensi Anemia dan Kurang Besi

\begin{tabular}{|c|c|c|c|c|c|c|c|c|c|c|c|c|}
\hline \multirow{2}{*}{$\begin{array}{l}\text { Kelompok umur } \\
\text { (tahun) dan Status } \\
\text { Zat Besi }\end{array}$} & \multicolumn{6}{|c|}{ Kota } & \multicolumn{6}{|c|}{ Desa } \\
\hline & $\mathrm{n}$ & Lk & $n$ & $\operatorname{Pr}$ & $n$ & Total & $\mathrm{n}$ & Lk & $n$ & $\operatorname{Pr}$ & $\mathrm{n}$ & Total \\
\hline \multicolumn{13}{|l|}{$0,5-0,9$} \\
\hline - Anemia & 16 & 55,2 & 19 & 54,3 & 35 & 54,7 & 29 & 65,9 & 23 & 57,5 & 52 & 61,9 \\
\hline \multicolumn{13}{|l|}{$1,0-2,9$} \\
\hline - Anemia & 40 & 43,5 & 38 & 42,7 & 78 & 43,1 & 56 & 47,1 & 67 & 51,1 & 123 & 49,2 \\
\hline - Kurang Besi & 6 & 18,2 & 5 & 16,1 & 11 & 17,2 & 12 & 27,9 & 15 & 31,3 & 27 & 29,7 \\
\hline \multicolumn{13}{|l|}{$3,0-5,9$} \\
\hline - Anemia & 32 & 22,7 & 41 & 33,1 & 73 & 27,5 & 46 & 26,3 & 34 & 20,5 & 80 & 23,5 \\
\hline - Kurang Besi & 10 & 8,1 & 6 & 6,1 & 16 & 7,2 & 12 & 9,3 & 6 & 4,9 & 18 & 7,1 \\
\hline \multicolumn{13}{|l|}{$6,0-8,9$} \\
\hline - Anemia & 23 & 13,3 & 22 & 12,4 & 45 & 12,8 & 43 & 17,7 & 38 & 14,4 & 81 & 16,0 \\
\hline - Kurang besi & 3 & 1,9 & 1 & 0,7 & 4 & 1,3 & 8 & 5,1 & 9 & 5,0 & 17 & 5,0 \\
\hline \multicolumn{13}{|l|}{$9,0-12,9$} \\
\hline - Anemia & 7 & 5,1 & 6 & 4,8 & 13 & 5,0 & 14 & 11,7 & 17 & 11,2 & 31 & 11,4 \\
\hline - Kurang Besi & 1 & 0,8 & 1 & 0,9 & 2 & 0,9 & 3 & 3,3 & 8 & 6,8 & 11 & 5,3 \\
\hline
\end{tabular}


Tabel 3

Prevalensi Kurang Vitamin A (KVA)

\begin{tabular}{lcccccccccccc}
\hline $\begin{array}{l}\text { Kelompok Umur } \\
\text { (tahun) }\end{array}$ & $\mathrm{n}$ & $\begin{array}{c}\mathrm{Lk} \\
(\%)\end{array}$ & $\mathrm{n}$ & $\begin{array}{c}\mathrm{Pr} \\
(\%)\end{array}$ & $\mathrm{n}$ & $\begin{array}{c}\text { Total } \\
(\%)\end{array}$ & $\mathrm{n}$ & $\begin{array}{c}\text { Lk } \\
(\%)\end{array}$ & $\mathrm{n}$ & $\begin{array}{c}\mathrm{Pr} \\
(\%)\end{array}$ & $\mathrm{n}$ & $\begin{array}{c}\text { Total } \\
(\%)\end{array}$ \\
\hline $1,0-2,9$ & 0 & 0,0 & 0 & 0,0 & 0 & 0,0 & 3 & 6,7 & 0 & 0,0 & 3 & 3,1 \\
$3,0-5,9$ & 4 & 3,3 & 4 & 4,2 & 8 & 3,7 & 4 & 3,1 & 4 & 3,1 & 8 & 3,1 \\
$6,0-8,9$ & 9 & 6,2 & 5 & 3,5 & 14 & 4,9 & 2 & 1,3 & 6 & 3,3 & 8 & 2,4 \\
$9,0-12,9$ & 7 & 6,3 & 3 & 3,2 & 10 & 4,9 & 4 & 4,4 & 6 & 5,2 & 10 & 4,8 \\
\hline
\end{tabular}

Tabel 4

Proporsi Status Anemia dan Anemia Kurang Besi

\begin{tabular}{lcrrr}
\hline $\begin{array}{l}\text { Kelompok Umur } \\
\text { (tahun) }\end{array}$ & Status anemia & \multicolumn{2}{c}{ Status ferritin(\%) } & \multirow{2}{*}{ Total(\%) } \\
\cline { 3 - 4 } $1,0-2,9$ & Normal & 54,9 & 7,8 & 62,7 \\
& Anemia & 20,3 & 17,0 & 37,3 \\
$3,0-5,9$ & Normal & 73,7 & 2,0 & 75,7 \\
& Anemia & 18,9 & 5,4 & 24,3 \\
$6,0-8,9$ & Normal & 83,6 & 2,6 & 86,3 \\
& Anemia & 12,9 & 0,8 & 13,7 \\
$9,0-12,9$ & Normal & 89,8 & 2,2 & 92,1 \\
& Anemia & 6,7 & 1,2 & 7,9 \\
\hline
\end{tabular}

Tabel 5

Proporsi Status Anemia dan Anemia Kurang Besi pada Anak Laki-Laki

\begin{tabular}{|c|c|c|c|c|c|c|c|}
\hline \multirow{3}{*}{$\begin{array}{l}\text { Kelompok } \\
\text { Umur (tahun) }\end{array}$} & \multirow{3}{*}{$\begin{array}{l}\text { Status } \\
\text { Anemia }\end{array}$} & \multicolumn{3}{|c|}{ Kota } & \multicolumn{3}{|c|}{ Desa } \\
\hline & & \multicolumn{2}{|c|}{ Status Feritin (\%) } & \multirow{2}{*}{$\begin{array}{l}\text { Total } \\
(\%)\end{array}$} & \multicolumn{2}{|c|}{ Status Feritin (\%) } & \multirow{2}{*}{$\begin{array}{l}\text { Total } \\
(\%)\end{array}$} \\
\hline & & Normal & Kurang & & Normal & Kurang & \\
\hline \multirow[t]{2}{*}{$1,0-2,9$} & Normal & 63,3 & 6,7 & 70,0 & 51,2 & 7,0 & 58,1 \\
\hline & Anemia & 20,0 & 10,0 & 30,0 & 20,9 & 20,9 & 41,9 \\
\hline \multirow[t]{2}{*}{$3,0-5,9$} & Normal & 75,7 & 0,9 & 76,5 & 72,9 & 3,1 & 76,0 \\
\hline & Anemia & 15,7 & 7,8 & 23,5 & 17,8 & 6,2 & 24,0 \\
\hline \multirow[t]{2}{*}{$6,0-8,9$} & Normal & 86,6 & 0,7 & 87,3 & 80,3 & 3,8 & 84,1 \\
\hline & Anemia & 11,9 & 0,7 & 12,7 & 14,6 & 1,3 & 15,9 \\
\hline \multirow[t]{2}{*}{$9,0-12,9$} & Normal & 93,5 & 0,9 & 94,4 & 87,2 & 3,5 & 90,7 \\
\hline & Anemia & 5,6 & 0,0 & 5,6 & 9,3 & 0,0 & 9,3 \\
\hline
\end{tabular}

Tabel 5 menunjukkan proporsi anak yang mengalami anemia dan anemia kurang besi pada anak laki-laki. Prevalensi anemia tinggi dijumpai pada kelompok usia muda $(1,0-2,9$ tahun) di perkotaan sebesar 30,0 persen dimana 10,0 persen adalah anemia kurang besi dan di perdesaan yaitu 41,9 persen dimana 20,9 persen adalah anemia kurang besi dibandingkan pada anak usia lebih tua $(9,0-12,9$ tahun) di perkotaan ditemukan proporsi anemia sebesar 5,6 persen dan tidak ditemukan $(0,0$ persen) anemia kurang besi, sedangkan di perdesaan proporsi anemia sebesar 9,3 persen dan tidak ditemukan anemia kurang besi $(0,0$ persen).

Tabel 6 menunjukkan proporsi anak yang mengalami anemia dan anemia kurang besi pada anak perempuan. Prevalensi anemia 
Tabel 6

Proporsi Status Anemia dan Anemia Kurang Besi pada Anak Perempuan

\begin{tabular}{|c|c|c|c|c|c|c|c|}
\hline \multirow{3}{*}{$\begin{array}{l}\text { Kelompok } \\
\text { Umur }\end{array}$} & \multicolumn{4}{|c|}{ Kota } & \multicolumn{3}{|c|}{ Desa } \\
\hline & \multirow{2}{*}{$\begin{array}{l}\text { Status } \\
\text { Anemia }\end{array}$} & \multicolumn{2}{|c|}{ Status Feritin (\%) } & \multirow{2}{*}{$\begin{array}{c}\text { Total } \\
(\%)\end{array}$} & \multicolumn{2}{|c|}{ Status Feritin (\%) } & \multirow{2}{*}{$\begin{array}{c}\text { Total } \\
(\%)\end{array}$} \\
\hline & & Normal & Kurang & & Normal & Kurang & \\
\hline \multirow[t]{2}{*}{$1,0-2,9$} & Normal & 73,3 & 0,0 & 73,3 & 43,8 & 12,5 & 56,3 \\
\hline & Anemia & 13,3 & 13,3 & 26,7 & 25,0 & 18,8 & 43,8 \\
\hline \multirow[t]{2}{*}{$3,0-5,9$} & Normal & 66,7 & 2,2 & 68,8 & 78,0 & 2,4 & 80,5 \\
\hline & Anemia & 26,9 & 4,3 & 31,2 & 17,1 & 2,4 & 19,5 \\
\hline \multirow[t]{2}{*}{$6,0-8,9$} & Normal & 87,2 & 0,0 & 87,2 & 83,3 & 3,9 & 87,2 \\
\hline & Anemia & 12,0 & 0,8 & 12,8 & 11,7 & 1,1 & 12,8 \\
\hline \multirow[t]{2}{*}{$9,0-12,9$} & Normal & 93,5 & 1,1 & 94,6 & 86,0 & 2,6 & 88,6 \\
\hline & Anemia & 5,4 & 0,0 & 5,4 & 7,0 & 4,4 & 11,4 \\
\hline
\end{tabular}

tinggi dijumpai pada kelompok usia muda $(1,0$ 2,9 tahun) di perkotaan sebesar 26,7 persen dimana 13,3 persen adalah anemia kurang besi dan di perdesaan yaitu 43,8 persen dimana 18,8 persen adalah anemia kurang besi dibandingkan pada anak usia lebih tua $(9,0-12,9$ tahun) di perkotaan ditemukan proporsi anemia sebesar 5,4 persen dan tidak ditemukan $(0,0$ persen) anemia kurang besi, sedangkan di perdesaan proporsi anemia sebesar 11,4 persen dan tidak ditemukan anemia kurang besi (0,0 persen).

\section{BAHASAN}

Hasil penelitian menunjukkan prevalensi anemia tertinggi pada kelompok anak usia muda dibandingkan kelompok anak usia lebih tua. Prevalensi anemia pada kelompok usia muda (0,5-0,9 tahun) sebesar 54,7 persen di perkotaan dan 61,9 persen di perdesaan. Temuan ini, hampir sama dengan temuan di Bangladesh dan laporan Mc Lean Erin et al. (2007) prevalensi anemia di Asia, yaitu masingmasing 60 dan 58 persen ${ }^{8,10}$, namun lebih tinggi bila dibandingkan dengan prevalensi anemia di Turki yaitu 40 persen 7 . Temuan lain dari penelitian ini adalah prevalensi anemia pada kelompok usia lebih tua (9,0-12,9 tahun) yaitu hanya 5,0 persen di perkotaan dan 11,4 persen di perdesaan. Prevalensi ini jauh lebih rendah dibandingkan prevalensi anemia kelompok usia lebih tua. Keadaan ini menunjukkan bahwa masalah anemia lebih berat pada kelompok yang lebih muda. Hal ini disebabkan anak-anak yang lebih tua sudah dapat makan lebih beragam dari pada kelompok anak usia muda. Besarnya proporsi anemia yang lebih besar pada kelompok usia muda dibandingkan pada kelompok lebih tua, juga dapat disebabkan ibu hamil menderita anemia, sehingga anak yang dilahirkan juga menderita anemia. Temuan ini diperkuat dengan hasil penelitian yang menyatakan bahwa anak yang lahir dari ibu anemia berisiko lahir dengan $\mathrm{Hb}$ rendah ${ }^{12}$, karena prevalensi anemia ibu hamil di Indonesia masih cukup tinggi yaitu 40,1 persen dan 24,5 persen. ${ }^{1,2}$

Bila dilihat dari kelompok jenis kelamin, proporsi anemia dan anemia kurang besi pada kelompok usia muda (1,0-2,9 tahun) tidak jauh berbeda antara anak perempuan dengan lakilaki, namun pada kelompok usia lebih tua $(9,0$ 12,9 tahun) proporsi anemia dan anemia kurang besi ditemukan lebih besar pada anak perempuan dibandingkan anak laki-laki. Hal ini kemungkinan disebabkan karena sebagian anak perempuan usia 9,0-12,9 sudah mendapat menstruasi sehingga mengalami kehilangan darah. Di negara sedang berkembang seperti di Indonesia, pada umumnya penyebab terbesar kejadian anemia adalah kekurangan zat besi akibat asupan zat besi yang rendah. ${ }^{4}$ Sementara itu, masa pertumbuhan cepat terjadi pada kelompok umur 9,0-12,9 tahun, sehingga tubuh memerlukan banyak zat besi untuk pertumbuhan. ${ }^{7}$ Pada penelitian ini untuk 
mengukur kurang zat besi digunakan analisis kadar ferritin. Kadar ferritin merupakan metoda paling baik untuk mengetahui cadangan besi di dalam tubuh. Pada kasus anemia kurang besi, kadar ferritin akan rendah (di bawah nilai normal), dan kadar $\mathrm{Hb}$ juga rendah. ${ }^{3}$ Oleh karena pengukuran ferritin sangat dipengaruhi adanya inflamasi maka semua sampel yang diukur kadar ferritin, ditapis (screening) lebih dulu dengan pengukuran $\mathrm{C}$-reactive Protein (CRP).

\section{SIMPULAN DAN SARAN}

\section{Simpulan}

Prevalensi anemia pada anak usia di bawah 3 tahun cukup tinggi yaitu sekitar 50-60 persen, hal ini menunjukkan bahwa anemia pada anak usia di bawah 3 tahun masih menjadi masalah kesehatan masyarakat dengan kategori berat. Kekurangan zat besi lebih banyak ditemui pada anak kelompok usia di bawah 3 tahun. Prevalensi anemia lebih tinggi di perdesaan dibandingkan dengan di perkotaan. Status vitamin A pada anak di Indonesia sudah membaik.

\section{Saran}

Berdasarkan temuan penelitian dimana anemia anak usia di bawah 3 tahun masih menjadi masalah kesehatan masyarakat berat, maka perbaikan masalah ini perlu dipertimbangkan pencegahan anemia dari sejak kehamilan.

\section{UCAPAN TERIMA KASIH}

Ucapan terima kasih kepada FrieslandCampina, Frisian Flag Indonesia dan Kepala Dinas kesehatan Propinsi dan kabupaten di 33 Propinsi yang telah membantu kelancaran penelitian ini sehingga penelitian ini dapat berjalan dengan baik.

\section{RUJUKAN}

1. Survei Kesehatan Rumah Tangga (SKRT), 2001. Jakarta: Badan Litbang Kesehatan, Departemen Kesehatan, 2001

2. Badan Libang Kesehatan. Riset Kesehatan Dasar 2007. Laporan Nasional. Jakarta: Badan Litbang Kesehatan, 2008
3. Sumarno I, Kartika V, Saraswati E. Prevalensi anemia pada anak usia 2-4 tahun di DKI Jakarta serta faktor risikonya. Gizi Indonesia. 2005;28 (1):22-31.

4. World Health Organization. Iron Deficiency Anemia. Assessment, Provention and control. Geneve: WHO, 2001

5. Semba RD, Bloem MW. The anemia of vitamin A deficiency: epidemiology and pathogenesis. Eur J Clinical Nutrition. 2002; 56(4);271-281.

6. Herman S, Studi Masalah Gizi Mikro Di Indonesia. Laporan Penelitian. Bogor: Pusat Penelitian dan Pengembangan Gizi dan Makanan, 2006.

7. Nhien-Nguyen, Nguyen-Cong K, Nguyen Xuan N, Phan Van H, Le Thi H, Nguyen Thi Lam, et.al. Micronutrient deficiencies and anemia among preschool children in rural vietnam.Asia Pac J Clin Nutr. 2008; 17(1):48-55.

8. Unsal A, Ozcan Bor, Mustafa T, Ener C, Gulsah E. Prevalence of anemia and related risk factors among 4-11 months age infants in eskisehir, Turkey. JMed Sci. 2007;7(8):1335-1339.

9. Child Development Unit, Clinical Sciences Devision, ICDDR,B. Prevalence of Irondeficiency anemia among young children in rural Bangladesh. Health and Science Bulletin. 2010; 8(2): 8-16

10. Sommer A, Davidson FR. Assessment and control of vitamin A deficiency. The annecy Accord. Proceeding of the XX International Vitamin A Consultative Group Meeting. New York: American Society for Nutritional Sciences, 2002.

11. McLean E, Cogswell, Egli Ines, Wojdyla D, and de Benoist B. World wide Prevalence of Anemia in Preschool Aged Children, Pregnant Women and non-pregnant Women of Reproductive Age. The Guidebook. Nutritional Anemia. Switzerland: Sight and Life Press., 2007.

12. De Pee-Saskia, Bloem, Mayangsari, Kiess L, Yip Ray, Kosen Soewarta. The high Prevalence of Low Hemoglobin concentration among Indonesian infants aged 3-5 months is related to maternal anemia. The Journal of Nutrition.2002. 132(8):2215-2221 . 